\title{
For-Profit Corporation
}

National Cancer Institute

\section{Source}

National Cancer Institute. For-Profit Corporation. NCI Thesaurus. Code C133310.

An organization which aims to earn profit through its operations and is concerned with its own interests. 